\title{
KEMUNGKINAN PERATURAN PERUNDANGAN-UNDANGAN DI BAWAH UNDANG-UNDANG SEBAGAI OBYEK PENGUJIAN MAHKAMAH KONSTITUSI
}

\author{
Thorkis Pane ${ }^{1}$
}

\begin{abstract}
Laws and regulations that emphasize written, originally closely associated with continental European legal systems that embrace legisme with civil law. While Angglo Saxon legal system (common law) emphasizes the role of institutions in shaping judicial ruling.In the Indonesian system of constitutional law, order (hierarchy) legislation as a source of law before the post-reform refers to a letter addressed to the President of the House of Representatives No.. 2262/HK/1959 dated August 20, 1959; amended by MPRS XX/MPRS/1966 No. DPR-GR Memorandum on the Law of the Republic of Indonesia Source Code and Sequence of Legislation of the Republic of Indonesia. With the enactment of Law No. 12 of 2011 which regulates the order of legislation, as a source of constitutional law in the Indonesian legal system in force today, and binding on all state agencies that are empowered to make laws.
\end{abstract}

Keywords:regulations,judicial reviews, constitutional court

\begin{abstract}
Abstrak
Hukum perundang-undangan yang menekankan pada bentuk tertulis, semula terkait erat dengan sistem hukum Eropa kontinental yang menganut legisme dengan civil law. Sedangkan dalam sistem hukum Angglo Saxon (common law) lebih menekankan kepada peranan lembaga yustisial dalam pembentukan hukumnya. Dalam sistem hukum ketatanegaraan Indonesia, tatanan (hirarki) peraturan perundang-undangan sebagai sumber hukum sebelum pasca reformasi mengacu kepada Surat Presiden yang ditujukan kepada DPR RI No. 2262/HK/1959 tertanggal 20 Agustus 1959; dirubah oleh Ketetapan MPRS Nomor XX/MPRS/1966 tentang Memorandum DPRGR mengenai Sumber Tertib Hukum Republik Indonesia dan Tata Urutan Perundangan Republik Indonesia. Dengan diundangkannya Undang-Undang Nomor 12 Tahun 2011 yang mengatur tentang tatanan peraturan perundang-undangan, sebagai sumber hukum dalam sistem hukum ketatanegaraan Indonesia yang berlaku
\end{abstract}

\footnotetext{
${ }^{1}$ Penulis adalah Staf Pengajar Mata Kuliah Praktek Hukum Acara Peradilan Tata Usaha, Fakulta Hukum Universiat Indonesia Negara. Alamat korespondensi:
} 
saat ini, dan mengikat semua lembaga negara yang diberi wewenang membuat peraturan perundang-undangan.

Kata kunci: perundang-undangan, pengujiann undang-undang, mahkamah konstitusi

\section{Pendahuluan}

Berakhirnya pemerintahan Orde Baru pada 21 Mei 1998 telah membawa bangsa Indonesia kepada pusaran tuntutan perubahan yang fundamental dalam berbagai bidang kehidupan berbangsa dan bernegara. Tuntutan reformasi hukum merupakan salah satu wacana yang berembus demikian kuatnya, khususnya pemikiran dapat dilakukannya perubahan terhadap Konstitusi (Undang-Undang Dasar Tahun 1945). Pemikiran tentang reformasi hukum sebagaimana yang dikumandangkan pada era reformasi tidak terlepas dari latar belakang fakta sejarah, begitu kuatnya kekuasaan yang dimiliki oleh Soeharto sebagai Presiden selama 32 tahun (tahun 1966-1998), dimana hukum (Undang-Undang Dasar Tahun 1945) dijadikan sebagai alat pembenar "justification" untuk mempertahankan kekuasaan, dan bukan untuk keadilan dan kesejahteraan rakyat. Lord Acton seorang ahli sejarah Inggris dalam dalilnya mengemukakan "Power tends to corrupt, but absolutte power corrupts absolutely" (Manusia yang mempunyai kekuasaan cenderung untuk menyalahgunakan kekuasaan itu, tetapi manusia yang mempunyai kekuasaan tak terbatas pasti akan menyalahgunakannya). ${ }^{2}$ Implikasi politik hukum yang dibangun dan diterapkan Orde Baru terpusat dibawah pengawasan kacamata Soeharto sebagai kepala pemerintahan, yang menimbulan beberapa permasalahan sebagai berikut:

1. Hukum yang tidak demokratis;

2. Hukum yang selalu ditentukan oleh kekuasaan;

3. Ketidaksamaan dihadapan hukum; dan

4. lemahnya "Law enforcement". ${ }^{3}$

Momentum tuntutan reformasi hukum dilakukannya politik hukum, melalui Sidang Umum MPR atas dasar ketentuan Pasal 37 UUD Tahun 1945 yakni

\footnotetext{
${ }^{2}$ Miriam Budiardjo, "Dasar-Dasar Ilmu Politik”, cet. Ke-tiga, (Jakarta: PT. Gramedia, 1977), hal. 52 .

${ }^{3}$ Ramly Hutabarat, "Politik Hukum Pemerintahan Soeharto Tentang Demokrasi Politik Di Indonesia", cet. Ke-satu, (Jakarta: Pascasarjana FHUI, 2004), hal. 163.
} 
perubahan (amandemen) terhadap Undang-Undang Dasar Tahun 1945. Sampai saat ini telah dilakukan sebanyak 4 (empat) kali perubahan mendasar yang dijadikan sebagai potret konstitusi pasca reformasi, dimana substansi pokok perubahan meliputi:

1. Pembagian kekuasaan berdasarkan UUD 1945;

2. Hubungan antar lembaga negara;

3. Otonomi daerah yang seluas-luasnya;

4. Penegakan hukum dan supremasi hukum. ${ }^{4}$

Menarik untuk disimak sebagai telaah kajian dalam tulisan ini adalah masalah perubahan terhadap substansi penegakan hukum dan supremasi hukum. Penegakan hukum dan supremasi hukum dapat dilihat dari kemandirian kekuasaan kehakiman, untuk menyelenggarakan peradilan yang merdeka, bebas dari intervensi dari pihak manapun, guna menegakkan hukum dan keadilan. Esensi dalam penegakan hukum, kekuasaan kehakiman sebagai salah satu kekuasaan negara dalam sistem ketatanegaraan Indonesia, berfungsi memutus sengketa hukum yang timbul antara anggota masyarakat satu sama lain serta antara anggota masyarakat dan pemerintah, dengan tujuan mewujudkan ketertiban umum melalui putusan yang adil.

Pasca reformasi setelah amandemen UUD 1945, kekuasaan kehakiman sebagai salah satu kekuasaan negara tidak lagi menjadi bagian dari kekuasaan eksekutif secara organisatoris, administratif dan finansial. Kekuasaan kehakiman adalah kekuasaan hukum yang mandiri, merdeka, bebas dari intervensi pihak manapun yang diselenggarakan oleh Mahkamah Agung dan Mahkamah Konstitusi. Pasal 24 ayat (2) UUD 1945, "Kekuasaan kehakiman dilakukan oleh sebuah Mahkamah Agung dan badan peradilan yang berada dibawahnya dalam lingkungan peradilan umum, lingkungan peradilan agama, lingkungan peradilan militer, lingkungan peradilan tata usaha negara, dan oleh sebuah Mahkamah konstitusi". ${ }^{5}$

Pasca amandemen, dari rumusan Pasal 24 ayat (2) UUD 1945 tersebut menarik untuk ditelaah adalah keberadaan Mahkamah Konstitusi, sebagai salah satu bentuk kekuasaan kehakiman yang sebelumnya tidak pernah dikenal sama sekali dalam sistem ketatanegaraan Indonesia. Secara filosofis ide dasar pembentukan Mahkamah Konstitusi adalah untuk menciptakan sebuah sistem ketatanegaraan di Indonesia yang menganut asas pemisahan kekuasaan (separation of power) secara fungsional

${ }^{4}$ A.M. Fatwa, "Potret Konstitusi Pasca Amandemen UUD 1945", cet. Ke-satu, (Jakarta: PT. Gramedia, 2009), hal. 8.

${ }^{5}$ Indonesia, (a), Undang - Undang Dasar 1945, Psl. 24 ayat (2). 
dan menerapkan "check and balances". Untuk menggantikan secara bertahap penggunaan asas pendistribusian kekuasaan (distribution of power) dan paham integralisme dari lembaga tinggi negara, dengan alasan bahwa:

1. Negara Indonesia merupakan negara hukum yang berdasarkan Pancasila dan UUD 1945, bertujuan untuk mewujudkan tata kehidupan bangsa dan negara yang tertib, bersih, makmur dan berkeadilan;

2. Mahkamah Konstitusi sebagai salah satu pelaku kekuasaan kehakiman mempunyai peranan penting dalam usaha menegakkan konstitusi dan prinsip negara hukum sesuai dengan tugas dan wewenangnya sebagaimana ditentukan oleh UUD 1945;

3. Berdasarkan ketentuan yang termuat dalam UUD 1945 ( Pasal 24C) pengaturan tentang pengangkatan dan pemberhentian hakim konstitusi, hukum acara dan ketentuan lainnya diatur dalam umdang-undang. ${ }^{6}$

Dalam negara konstitusional yang demokratis keberadaan Mahkamah Konstitusi sebagai lembaga pengawal konstitusi (the guardian of the constitution) dengan kewenangan yang dimiliki melakukan pengujian peraturan "judicial review", untuk mejamin agar norma dasar (konstitusi) yang terkandung didalamnya sungguhsungguh ditaati dan dilaksanakan. ${ }^{7}$ Karenanya keberadaan Mahkamah Konstitusi sebagai bagian dari pelaku kekuasaan kehakiman dalam Negara Hukum RI adalah untuk menangani perkara ketatanegaraan atau perkara konstitusi tertentu dalam rangka menjaga konstitusi (UUD 1945) agar dilaksanakan secara bertanggung jawab sesuai dengan kehendak rakyat dan cita-cita demokrasi.

Keberadaan Mahkamah Konstitusi sekaligus untuk menjaga pemerintahan negara yang stabil, dan juga merupakan koreksi terhadap pengalaman kehidupan ketatanegaraan dimasa lalu yang ditimbulkan oleh tafsir ganda terhadap konstitusi. ${ }^{8}$

${ }^{6}$ Abdul Rasyid Thalib, "Wewenang Mahkamah Konstitusi dan Imlikasinya dalam Sistem Ketatanegaraan Republik Indonesia”, cet. Ke-satu, (Bandung: PT. Citra Aditya Bakti, 2006), hal. 167168 .

${ }^{7}$ Jimly Asshidiqie, (a), "Model-Model Pengujian Konstitusional Di Berbagai Negara", cet. Kedua, (Jakarta: KONpress,2005), hal. 19-20. "Dari sinilah kemudian berkembang pengertian bahwa Mahkamah Agung pada pokoknya merupakan lembaga pengawal konstitusi (the guardian of the constitution of the United State of America), ...........kewenangan inilah yang kemudian dikenal sebagai doktrin 'judicial review'. 
Selaku pengawal konstitusi (the guardian of the constitution) Mahkamah Konstitusi sebagai badan peradilan pada tingkat pertama dan terakhir diberi kewenangan untuk melakukan pengujian (judicial review) undang-undang terhadap Undang-Undang Dasar, sebagaimana yang disebutkan dalam Pasal 24C UUD 1945. Putusan mana bersifat final artinya, terhadap putusan Mahkamah Konstitusi dalam pengujian tersebut tidak dapat dilakukan upaya hukum lebih lanjut.

Sedangkan pengujian peraturan perundang-undangan dibawah Undang-Undang adalah menjadi kewenangan Mahkamah Agung dan pengujian tersebut dilakukan terhadap Undang-Undang (Pasal 24A ayat 1 UUD 1945 jo Pasal 31 ayat 1 UU No. 5 Tahun 2004 tentang Mahkamah Agung). Menjadi persoalan dalam praktek ketatanegaraan bukan tidak mungkin peraturan perundang-undangan dibawah Undang-Undang yang menjadi produk lembaga pemerintah sebagai badan politik melanggar dan merugikan hak-hak konstitusi masyarakat. Hal ini merupakan suatu dilemma dalam kehidupan ketatanegaraan, apabila ketentuan Pasal 24C UUD 1945 diperlakukan secara kaku dan limitatif. Persoalan inilah yang menjadi pokok bahasan dalam tulisan ini, yang kiranya dapat menjadi pemikiran dalam perkembangan hukum dikemudian hari.

\section{Tentang "Judicial Review"}

Pemikiran tentang pengujian konstitusional "Judicial review" pertama kali muncul dalam sistem hukum Amerika Serikat, berawal dari penyelesaian kasus Marbury versus Madison, tahun 1803. Adalah John Marshall sebagai ketua Mahkamah Agung (Chief justice) pada saat itu yang berperan penting dalam penyelesaian kasus Marbury versus Madison dengan memperkenalkan mekanisme 'constitutional review' atau 'judicial review' ini pertama kali dalam praktek peradilan di Amerika Serikat. 9

Kasus Marbury versus Madison, berawal dari ditandatanganinya surat pengangkatan pejabat-pejabat penting pemerintah Amerika Serikat (Thn. 1801) oleh John Marshall selaku Sekretaris Negara (Secretary of State) pada saat itu, menjelang peralihan Pemerintahan John Adams kepada Presiden terpilih Thomas Jefferson. Pejabat-pejabat tersebut antara lain William Marbury, Dennis Ramsay, Robert Townsend Hooe, dan William Harper yang diangkat menjadi hakim perdamaian

8 Abdul Mukthie Fadjar, "Hukum Konstitusi Dan Mahkamah Konstitusi", cet. Ke-satu, (Jakarta: KONpress, 2006), hal. 119.

${ }^{9}$ Asshiddiqie, (a), Op. Cit., hal. 16. 
(justices of peace). Menurut lawan politik John Adams, pengangkatan pejabatpejabat tersebut sengaja dilakukan untuk menyelamatkan sahabat-sahabatnya sendiri supaya mendapatkan kedudukan-kedudukan yang penting dalam pemerintahan. Termasuk, Secretary of State Jhon Marshall yang diangkat menjadi Ketua Mahkamah Agung (Chief Justice). ${ }^{10}$

Sayangnya, salinan surat pengangkatan pejabat-pejabat tersebut tidak sempat lagi diserah terimakan sebagaimana mestinya. Surat-surat tersebut masih berada dikantor kepresidenan yang ditahan oleh James Madison selaku Secretary of State yang diangkat oleh Presiden Thomas Jefferson untuk menggantikan Jhon Marshall. Atas dasar penahanan surat tersebut William Marbury Cs. melalui kuasa hukumnya Carles Lee mantan Jaksa Agung Federal mengajukan tuntutan ke Mahkamah Agung (Supreme of Court) yang dipimpin oleh Jhon Marshall. Dalam gugatannya William Marbury Cs. dengan alasan pengangkatan mereka menjadi hakim telah mendapat persetujuan Kongres dan pengangkatan itu telah pula dituangkan dalam Keputusan Presiden yang telah ditandatangani dan telah dicap resmi (sealed). Menuntut agar Mahkamah Agung sesuai dengan kewenangannya memerintahkan Pemerintah melaksanakan tugas yang dikenal sebagai 'writ of mandamus' dalam rangka penyerahan surat-surat pengangkatan tersebut. Adapun yang menjadi alasan hukum William Marbury Cs. (Penggugat), adalah ketentuan yang diatur dalam Section 13 Judiciary Act Tahun 1789, bahwa Mahkamah Agung berwenang memeriksa dan memutus perkara yang mereka ajukan serta mengeluarkan 'writ of mandamus' sebagaimana yang mereka tuntut. ${ }^{11}$

Dalam Putusan Mahkamah Agung, sebagaimana pertimbangan hukumnya bahwa Pemerintahan John Adams sebelumnya telah melakukan semua persyaratan yang ditentukan oleh hukum sehingga William Marbury Cs. dianggap memang berhak atas surat-surat pengangkatan mereka itu menurut hukum; Namun demikian Mahkamah Agung menyatakan tidak berwenang memerintahkan kepada aparat pemerintah untuk menyerahkan surat-surat pengangkatan dimaksud; bahwa apa yang diminta oleh Penggugat, yaitu agar Mahkamah Agung mengeluarkan 'writ of mandamus' sebagaimana yang ditentukan dalam Section 13 Judiciary Act Tahun 1789 tidak dapat dibenarkan, karena ketentuan Judiciary Act 1789 itu sendiri justru bertentangan dengan Article III Section 2 Konstitusi Amerika Serikat. ${ }^{12}$

\footnotetext{
${ }^{10}$ Ibid., hal. 17.

${ }^{11}$ Ibid., hal. 18.

12 Ibid., hal. 19.
} 
Pertimbangan hukum yang dipakai Mahkamah Agung di bawah pimpinan Chief Justice John Marshall untuk memeriksa perkara Marbury Cs versus Madison, bukanlah melalui pintu Judiciary Act Tahun 1789, melainkan melalui kewenangan yang ditafsirkan dari Konstitusi. Menurut John Marshall segala undang-undang buatan Kongres, apabila bertentangan dengan Konstitusi sebagai 'the supreme law of the land' harus dinyatakan 'null and void'. Kewenangan inilah yang kemudian dikenal sebagai doktrin 'judicial review' sebagai sesuatu yang sama sekali baru dalam perkembangan sejarah hukum di Amerika Serikat sendiri dan juga di dunia. ${ }^{13}$

Simpul hukum yang dapat ditarik dari kasus tersebut, meskipun dalam pertimbangan hukum Mahkamah Agung membenarkan hak William Marbury Cs, adalah sah menurut hukum, akan tetapi gugatan William Marbury Cs ditolak, oleh karena Mahkamah Agung menyatakan tidak berwenang mengeluarkan 'writ of mandamus' seperti yang dimohonkan. Namun demikian putusan Mahkamah Agung tersebut menjadi sangat penting dalam perkembangan hukum, dimana putusan Mahkamah Agung justru membatalkan Undang-Undang yang mengatur tentang 'writ of mandamus' itu sendiri, yang dinilai bertentangan dengan ketentuan Section 2 Artcle III UUD Amerika Serikat. ${ }^{14}$

Dalam sistem peradilan Amerika Serikat Model "judicial review" sepenuhnya dilakukan oleh Mahkamah Agung dengan status 'the Guardian of the Constitution'; disamping itu terhadap persoalan-persoalan konstitusionalitas "judicial review" juga dilakukan oleh pengadilan biasa melalui prosedur yang dinamakan pengujian terdesentralisasi atau pengujian tersebar (a decentralized or diffuse or dispersed review). Artinya, pengujian demikian itu tidak bersifat institusional sebagai perkara yang berdiri sendiri, melainkan termasuk di dalam perkara lain yang sedang diperiksa oleh Hakim dalam semua lapisan pengadilan. Putusan pengadilan hanya mengikat para pihak yang bersengketa (inter partes), kecuali dalam kerangka prinsip 'stare decisis' mengharuskan hakim pengadilan dikemudian hari terikat untuk mengikuti putusan serupa yang telah diambil sebelumnya oleh hakim lain dalam kasus yang serupa (precedent). ${ }^{15}$

Model "Judicial Review" yang dilakukan oleh John Marshall selaku ketua Mahkamah Agung (supreme of court) selanjutnya menjadi konvensi di Amerika Serikat dan menjalar serta diikuti oleh berbagai negara di belahan dunia termasuk

\footnotetext{
13 Ibd., hal. 20.

14 Ibid.

15 Ibid., hal. 47.
} 
Indonesia, dengan berbagai variasinya dan perbedaannya tergantung dari sistem hukum yang dianut. Eropa Kontinental yang menganut ajaran 'civil law', pada umumnya menekankan pada peran lembaga legislatif dan eksekutif untuk membuat hukum-hukum tertulis, sedangkan sistem Anglo Saxon menekankan pada peran lembaga yudisial untuk membuat hukum melalui vonis-vonisnya yang kreatif dengan menggali nilai-nilai keadilan yang hidup di dalam masyarakat.

Kehadiran sistem pengujian konstitusional atau yang lebih dikenal dengan istilah 'judicial review' terus berkembang dalam praktek di berbagai negara demokrasi. Pada umumnya disambut sangat antusias baik didunia akademis maupun dalam praktek ketatanegaraan, bahkan tidak kurang dalam lingkungan kekuasaan kehakiman itu sendiri. Mekanisme pengujian hukum ini diterima sebagai cara negara hukum modern untuk mengendalikan dan mengimbangi (chek and balance) kecendrungan kekuasaan yang digenggam para pejabat pemerintahan untuk mernjadi sewenang-wenang. ${ }^{16}$

Mengenai pengujian hukum terhadap konstitusi ini Porf. Dr. Jimly Asshiddiqie, S.H., M.H., dalam bukunya 'Model-Model Pengujian Konstitusional Di Berbagai Negara', membedakan antara antara pengujian 'constitutional review' dan 'judicial review'. Adapun yang menjadi alasasan-alasan beliau adalah sebagai berikut: Pertama, 'constitutional review' selain dilakukan oleh hakim dapt pula dilakukan oleh lembaga selain hakim atau pengadilan, tergantung kepada lembaga mana UUD memberikan kewenangan untuk melakukannya. Kedua, konsep 'judicial review' terkait pula pengertian yang lebih luas obyeknya, misalnya mencakup soal legalitas peraturan dibawah Undang-Undang terhadap Undang-Undang; sedangkan 'constitusional review' hanya menyangkut pengujian konstitutionalitasnya, yaitu terhadap Undang-Undang Dasar. ${ }^{17}$

Lebih lanjut beliau mengemukakan, bahwa pengujian konstitusionalitas itu merupakan upaya hukum yang dapat dilakukan oleh siapa saja atau lembaga mana saja, tergantung kepada siapa atau lembaga mana kewenangan itu diberikan secara resmi oleh konstitusi suatu negara. Seperti dalam sistem Perancis, disebut 'Conceil Constitutional' yang memang bukan 'Cour' atau pengadilan sebagai lembaga hukum, melainkan Dewan Konstitusi yang merupakan lembaga politik. Jika dipakai istilah 'judicial review', maka dengan sendirinya berarti bahwa lembaga yang menjadi subyeknya adalah pengadilan atau lembaga 'judicial' (judiciary). Namun dalam konsepsi 'judicial review', cakupan pengertiannya sangat luas tidak saja

\footnotetext{
${ }^{16}$ Ibid., hal. 2.

${ }^{17}$ Ibid., hal. 3.
} 
menyangkut segi-segi konstitusionalitas sebagai obyek yang diuji, melainkan menyangkut pula segi-segi legalitasnya berdasarkan peraturan perundang-undangan di bawah Undang-Undang Dasar. ${ }^{18}$

\section{Peraturan Perundang-Undangan}

Umumnya peraturan perundang-undangan adalah semua hukum dalam arti luas yang dibentuk dengan cara tertentu, oleh pejabat yang berwenang dan dituangkan dalam bentuk tertulis. Dalam arti luas tersebut sebenarnya hukum dapat diartikan juga sebagai putusan hakim, terutama yang sudah berkekuatan hukum tetap dan yang telah menjadi yurisprudensi. Hukum perundang-undangan yang menekankan pada bentuk tertulis ini semula terkait erat dengan sistem hukum Eropa kontinental yang menganut legisme dengan civil law. Sedangkan dalam sistem hukum Angglo Saxon (common law) lebih menekankan kepada peranan lembaga yustisial dalam pembentukan hukumnya. ${ }^{19}$

Oleh karenanya perbedaan antara sistem hukum Eropa kontinental (civil law) dan Anglo Saxon (common law) dewasa ini lebih tertuju pada tumpuan strategi pembangunan hukumnya, yang satu menekankan pada peran lembaga legislatif dan eksekutif untuk membuat hukum-hukum tertulis, sedangkan yang satunya lebih menekankan pada peran lembaga yudisial untuk membuat hukum melalui vonisvonisnya yang kreatif dengan menggali nilai-nilai keadilan di dalam masyarakat. ${ }^{20}$

Dalam arti khusus, pengertian peraturan perundang-undangan adalah secara keseluruhan susunan hirarkhis peraturan perundang-undangan yang berbentuk Undang-Undang ke bawah, yaitu semua produk hukum yang melibatkan peran lembaga perwakilan rakyat bersama-sama dengan pemerintah ataupun melibatkan peran pemerintah karena kedudukan politiknya dalam rangka melaksanakan produk legislatif yang ditetapkan oleh lembaga perwakilan rakyat bersama-sama dengan pemerintah menurut tingkatannya masing-masing. Disamping itu juga termasuk dalam pengertian tersebut $\mathrm{di}$ atas adalah segala perangkat peraturan yang tingkatannya di bawah UU dan dimaksudkan untuk melaksanakan ketentuan yang

${ }^{18}$ Ibid., hal 3.

${ }^{19}$ Moh. Mahfud M.D., "Konstitusi Dan Hukum Dalam Kontroversi Isu”, cet. Ke-satu, (Jakarta: PT. RadjaGrafindo Persada, 2009), hal. 255.

20 Ibid., hal. 255. 
termuat dalam bentuk peraturan yang tingkatannya lebih tinggi. Sebagai konsekwensi dianutnya ajaran pemisahan kekuasaan legislatif dan eksekutif secara tegas, maka para pejabat yang dapat dianggap memiliki kewenangan demikian itu adalah Presiden, Menteri dan pejabat setingkat Menteri. Sedangkan para pejabat dalam birokrasi pemerintahan yang terkait menurut ketentuan peraturan kepegawainegerian tidak dapat diberi wewenang menetapkan peraturan sama sekali, mengingat jabatannya murni bersifat eksekutif. ${ }^{21}$

Istilah perundang-undangan (legislation, wetheving, gesetzhebung) dalam kepustakaan memberikan dua pengertian yang berbeda. Dalam kamus umum 'Inggris-Indonesia', legislation berarti perundang-undangan dan pembuatan undangundang. ${ }^{22}$ Sedangkan wetheving berarti:

1. Merupakan proses pembentukan atau proses membentuk peraturan negara, baik ditingkat pusat maupun di tingkat daerah;

2. Segala perturan negara yang merupakan hasil pembentukan peraturan, baik ditingkat pusat maupun di tingkat daerah. ${ }^{23}$

Dalam makalahnya yang disampaikan dalam pertemuan ilmiah di Jakarta 1994, Prof. Bagir Manan meninjau dari substansi peraturan perundang-undangan dengan memberikan pengertian sebagai berikut:

1. Sebagai keputusan tertulis yang dikeluarkan pejabat atau lingkungan jabatan yang berwenang yang berisi aturan tingkah laku yang bersifat atau mengikat umum;

2. Merupakan atauran-aturan tingkah laku yang berisi ketentuan-ketentuan mengenai hak, kewajiban, fungsi, status atau suatu tatanan;

3. Merupakan peraturan yang mempunyai ciri-ciri umum-abstrak atau abstrakumum, artinya tidak mengatur atau tidak ditujukan pada obyek, peristiwa atau gejala konkret tertentu;

4. Dengan mengambil pemahaman dalam keputusan Belanda, peraturan perundangundangan lazim disebut dengan wet in materiele zin, atau sering juga disebut

${ }^{21}$ Jimly Assiddiqie, (b), "Konstitusi \& Konstitusionalisme Indonesia", cet. Ke-satu, (Jakarta: Mahkamah Konstitusi RI \& Pusat Studi Hukum Tata Negara FHUI, 2004), hal. 256.

${ }^{22}$ John M. Echols dan Hasan Shadely, "Kamus Inggris-Indonesia”, cet. Ke-lima belas (Jakarta: PT. Gramedia, 1987), hal. 353.

${ }^{23}$ Mr. N.E. Algra, dkk, "Kamus Istilah Hukum Fockema Andreae Belanda-Indonesia", cet. Pertama, (Jakarta: Binacipta, 1983), hal. 684. 
dengan algemeen verbindende voorschrift yang meliputi antara lain: de supranationale algemeen verbindende voorschriften, wet, $A m v B$, de Ministeriele veroordening, de gemeeentelijke raadsverordeningen, de provinciale taten verordeningen. ${ }^{24}$

Ditinjau dari sudut sifat norma hukum yang diperlakukan peraturan perundangundangan dapat dikelompokkan dalam beberapa jenis yaitu: (i) keputusan yang bersifat mengatur (regeling) menghasilkan produk peraturan (regels), yaitu norma umum-abstrak dan berlaku terus menerus, (ii) keputusan hukum yang bersifat menentukan atau menetapkan sesuatu secara administratif menghasilkan keputusan administratif negara (beshikking), yaitu norma individual-konkret dan berlaku sekali selesai, dan (iii) keputusan yang bersifat menghakimi sebagai hasil dari proses peradilan (adjudication) menghasilkan putusan (vonnis). Disamping itu, ada pula yang dinamakan sebagai beleidregel atau aturan kebijakan (policy rules) yang sering disebut juga sebagai quasi peraturan, seperti petunjuk pelaksanaan, surat edaran, instruksi, dan sebagainya yang tidak dapat dikategorikan peraturan, tetapi isinya bersifat mengatur juga. ${ }^{25}$

Hans Kelsen, yang dikenal dengan ajaran 'teori hukum murni' dalam bukunya "General Theory of Law and State" menelaah norma hukum yang berlaku pada suatu negara. Dikemukakan bahwa norma-norma hukum itu berjenjang-jenjang dan berlapis-lapis dalam suatu hirarkhi tata susunan, dimana suatu norma yang lebih rendah berlaku bersumber dan berdasar pada norma yang lebih tinggi, dan norma yang lebih tinggi berlaku bersumber dan berdasar pada norma yang lebih tinggi lagi, demikian seterusnya sampai pada suatu norma yng tidak dapat ditelusuri lebih lanjut dan bersifat hipotetis dan fiktif, yaitu norma dasar (grundnorm) ${ }^{26}$

Teori hirarkhi norma hukum dari Hans Kelsen tersebut diilhami dari ajaran muridnya yang bernama Adolf Merkl yang mengemukakan bahwa suatu norma hukum itu selalu mempunyai dua wajah (das Dopplte Rechtsantlitz). Suatu norma

\footnotetext{
${ }^{24}$ Bagir Manan, Ketentuan-Ketentuan Tentang Pembentukan Peraturan Perundang-Undangan Daklam Pembangunan Hukum Nasional, makalah disampaikan pada pertemuan ilmiah tentang Kedudukan Biri-biro Hukum/Unit Kerja Departemen/LPND dalam Pembangunan Hukum, (Jakarta 19-20 Oktober 1994), hal. 1-3.

${ }^{25}$ Jimly Asshiddiqie, (c), "Pokok-Pokok Hukum Tata Negara Indonesia", cet. Ke-dua, (Jakarta: PT. Bhuana Ilmu Populer, 2008), hal. 209.

26 Maria Farida Indrati Soeprapto, "Ilmu Perundang-Undangan Dasar-dasar dan Pembentukannya", cet. Ke-sebelas, (Jakarta: Kanisius, 1998), hal. 25.
} 
hukum itu ke atas ia bersumber dan berdasar pada norma yang di atasnya, tetapi ke bawah ia juga menjadi dasar dan menjadi sumber bagi norma hukum di bawahnya, sehingga suatu norma hukum itu mempunyai masa berlaku (rechtskracht) yang relatif. Oleh karena masa berlakunya suatu norma hukum itu tergantung pada norma hukum yang berada diatasnya, sehingga apabila norma hukum yang berada di atasnya dicabut atau dihapus, maka norma-norma hukum yang berada dibawahnya tercabut atau terhapus pula. ${ }^{27}$

Berikutnya, teori Hans kelsen tersebut dikembangkan oleh muridnya Hans Nawiasky dalam bukunya "Allgemeine Rechtslehre", dikemukakan bahwa norma hukum tersebut selain berjenjang dan berlapis juga berkelompok-kelompok. Dalam hal ini Hans Nawiasky mengkelompokkannya dalam 4 (empat) kelompok yaitu :

1. Staatsfundamentalnorm (Norma Fundamental Negara)

2. Staatsgrundgesetz (Aturan dasar/Pokok Negara)

3. Formell Gesetz (Undang-undang 'formal')

4. Veroordnung \& Autonome Satzung (Aturan pelaksana \& atauran otonom) ${ }^{28}$

Dalam sistem hukum ketatanegaraan Indonesia, tatanan (hirarki) peraturan perundang-undangan sebagai sumber hukum sebelum pasca reformasi mengacu kepada Surat Presiden yang ditujukan kepada DPR RI No. 2262/HK/1959 tertanggal 20 Agustus 1959; dirubah oleh Ketetapan MPRS Nomor XX/MPRS/1966 tentang Memorandum DPR-GR mengenai Sumber Tertib Hukum Republik Indonesia dan Tata Urutan Perundangan Republik Indonesia.

Oleh karena Sumber Tertib Hukum dan Tata Urutan Peraturan Perundangan berdasarkan Ketetapan MPRS Nomor XX/MPRS/1966 dianggap tidak sempurna, menimbulkan kekacauan pengertian, sehingga tidak dapat lagi dijadikan sebagai landasan penyusunan peraturan perundang-undangan. Pasca reformasi dikeluarkanlah Ketetapan MPR Nomor III/MPR/2000 tentang Sumber Hukum dan Tata Urutan Peraturan Perundang-Undangan, tanggal 18 Agustus 2000. Namun demikian oleh karena Tap MPR Nomor III/MPR/2000 dibuat dalam keadaan tergesagesa dan tidak sesuai dengan amandemen UUD 1945, karenanya banyak mengandung kelemahan yang sangat serius. Untuk itu koreksi dan penyempurnaannya dilakukan dengan diundangkankannya Undang-Undang Nomor 12 Tahun 2011 tentang Pembentukan Peraturan Perundang-Undangan. ${ }^{29}$

\footnotetext{
${ }^{27}$ Ibid., hal. 26.

${ }^{28}$ Ibid., hal. 27.
} 
Adapun yang menjadi pertimbangan hukum diundangkannya Undang-Undang Nomor 12 Tahun 2011 tentang Pembentukan Peraturan Perundang-Undangan, adalah sebagai berikut:

1. Bahwa pembentukan peraturan perundang-undangan merupakan salah satu syarat dalam rangka pembangunan hukum nasional yang hanya dapat terwujud apabila didukung oleh cara dan metode yang pasti,baku dan standar yang mengikat semua lembaga yang berwenang membuat peraturan perundang-undangan;

2. Bahwa untuk lebih meningkatkan koordinasi dan kelancaran proses pembentukan peraturan peraturan perundang-undangan, maka negara Republik ndonesia sebagai negara yang berdasar atas hukum perlu memiliki peraturan mengenai pembentukan peraturan perundang-undangan;

3. Bahwa selama ini ketentuan yang berkaitan dengan pembentukan peraturan perundang-undangan terdapat dalam beberapa peraturan perundang-undangan yang sudah tidak sesuai lagi dengan hukum ketatanegaraan Republik Indonesia. ${ }^{30}$

Dengan diundangkannya Undang-Undang Nomor 12 Tahun 2011 yang mengatur tentang tatanan peraturan perundang-undangan, sebagai sumber hukum dalam sistem hukum ketatanegaraan Indonesia yang berlaku saat ini, dan mengikat semua lembaga negara yang diberi wewenang membuat peraturan perundangundangan. Dalam Pasal 7 ayat (1) Undang-Undang Nomor 12 Tahun 2011 tersebut menentukan tentang 'Jenis dan hierarki Peraturan Perundang-Undangan' adalah sebagai berikut:

1. Undang-Undang Dasar Negara Republik Indonesia Tahun 1945;

2. Undang-Undang/Peraturan Pemerintah Pengganti Undang-ndang;

3. Peraturan Pemerintah;

4. Peraturan Presiden;

5. Peraturan Daerah.

Berikutnya selain dari peraturan perundang-undangan sebagaimana yang dimaksud dalam Pasal 7 ayat (1) Undang-Undang tersebut, juga termasuk peraturanperaturan lain dan diakui keberadaannya dan mempunyai kekuatan hukum mengikat sepanjang diperintahkan oleh Peraturan Perundang-Undangan yang lebih tinggi, yaitu : peraturan yang dikeluarkan oleh MPR dan DPR, Mahkamah Agung, Mahkamah Konstitusi, Badan Pemeriksa Keuangan, Bank Indonesia, Menteri,

${ }^{29}$ Indonesia, (b), Undang-Undang tentang Pembentukan Peraturan Perundang-Undangan, UU No. 10 tahun 2004, LN No. 53 Tahun 2004, TLN No. 4389.

${ }^{30}$ Ibid., Bag. Konsideran. 
Kepala Badan, Lembaga, atau Komisi yang setingkat yang dibentuk oleh Undangundang atau Pemerintah atas perintah Undang-Undang, Dewan Perwakilan Rakyat Daerah Kabupaten/Kota, Bupati/Walikota, Kepala Desa atau yang setingkat (Pasal 7 ayat 4 Jo. Penjelasan UU No. 12 Tahun 2011).

Selanjutnya kekuatan hukum peraturan perundang-undangan sebagaimana yang dimaksud dalam Pasal 7 ayat (1) Undang-undang tersebut berlaku secara hirarkis, artinya berlaku asas bahwa peraturan perundang-undangan yang lebih rendah tidak boleh bertentangan dengan Peraturan Perundang-undangan yang lebih tinggi (Pasal 7 ayat 5 Jo. Penjelasan UU No. 12 Tahun 2011).

Hal yang menjadi persoalan dan mendapat kritikan Prof. Dr. Jimly Asshiddiqie, S.H., M.H., adalah penjabaran lebih lanjut dalam Pasal 7 ayat (2) hurup c Undang-Undang Nomor 11 Tahun 2011, masalah Peraturan Desa sebagai bagian dalam pengertian peraturan perundang-undangan negara. Sebagaimana dikemukan oleh beliau, Desa adalah tiang masyarakat bernegara, oleh karena itu kedudukannya dapat dipandang sangat penting bagi negara Republik Indonesia yang sebagian terbesar penduduknya hidup di desa. Akan tetapi memperlakukan peraturan desa sebagai bagian dari pengertian peraturan perundang-undangan negara bukanlah sesuatu yang logis dan dapat diterima. Karena itu urusan masyarakat dan pemerintahan desa sudah seharusnya diperklakukan sebagai komunitas masyarakat yang dapat mengurus dirinya sendiri atau "self governing communities", sehingga tidak perlu dicampuri oleh pemerintah. Oleh sebab itu pula peraturan desa tidak perlu diperlakukan sebagai bagian dari pengertian peraturan perundang-undangan negara. Negara cukup mengatur rambu-rambu bagi perikehidupan masyarakat dan pemerintahan desa itu sebagai form dan media pendidikan untuk hidup sejahtera dan berkeadilan, damai dan demokrasi. Artinya, kehidupan desa itu merupakan miniatur kehidupan bernegara dalam arti yang sebenarnya, sehingga segala norma yang berlaku di dalamnya tidak perlu di'negara'kan. Lagi pula dengan pe-negaraan urusan pedesaan itu, negara dapat terjerumus ke dalam paham etatisme atau paham serba negara yang berbahaya bagi paham demokrasi. ${ }^{31}$

\section{Mahkamah Konstitusi \& Kontroversi}

Pemikiran tentang 'Mahkamah Konstitusi' sebenarnya sudah pernah mencuat dipermukaan pada saat rapat besar Panitia Persiapan Penyelidik Kemerdekaan (PPPKI) dalam rangka merancang UUD (Thn. 1945). Adalah Mr. Moh. Yamin yang

\footnotetext{
${ }^{31}$ Asshiddiqie, (c), Op. Cit., hal. 221.
} 
mengajukan pertama kali, dimana beliau menghendaki dibentuknya Balai Agung atau Mahkamah Tinggi yang berhak menetapkan suatu Undang-Undang bertentangan dengan UUD. Pemikiran tersebut mengacu pada sistem hukum yang berlaku di Amerika Serikat, dimana pengadilan dapat menetapkan suatu undangundang "unconstitutional". Usulan Mr. Moh. Yamin tersebut ditolak oleh Prof. Mr. Dr. Soepomo, selaku Ketua Panitia Kecil Perancang UUD, dengan mengatakan "memang maksud sistem yang diajukan oleh Yamin, ialah supaya kekuasaan kehakiman mengontrol kekuasaan undang-undang"32 Adapun yang menjadi alasan Soepomo, yaitu: Pertama, UUD 1945 dibangun menurut prinsip-prinsip yang tidak didasarkan atas teori trias politica Montesquieu; Kedua, jumlah sarjana hukum masa awal kemerdekaan belum cukup untuk menjalankan tugas pembanding undangundang seperti yang dimaksud oleh Yamin. Lagi pula, menurut Soepomo, untuk memberikan kewenangan pembanding undang-undang kepada Balai Agung (Mahkamah Agung), masih diperlukan studi yang mendalam mengenai berbagai Verfassungsgerichtshof atau Mahkamah Konstitusi seperti di Austria, Cekoslovakia, dan Jerman di masa weimar, yang tidak dapat dilakukan dalam waktu singkat. ${ }^{33}$

Menelaah periode ketentuan UUD 1949 tentang kontrol yudikatif terhadap eksekutif dan legislatif tidak terdapat ketentuan yang mengatur secara langsung. Pasal 156, 157 dan 158 UUD 1949 hanya memberikan kewenang kepada Mahkamah Agung penyelesaian perselisihan kewenangan (conflct in competency) antara pemerintah daerah bagian dan pemerintah federal; akan tetapi tidak dalam kewenangan pengadilan menilai isi suatu UU federal, bahkan dalam Pasal 130 ayat 2 UU pemerintah Federal menyebutkan UU Federal tidak dapat diganggu gugat.

Demikian halnya dengan UUD 1950, sebagaimana disebutkan dalam Pasal 95 ayat 2 UUD 1950 'Pengadilan tidak berwenang untuk menilai isi undang-undang'.

Sebagaimana periode UUD 1949, UUD 1950, pada periode kembali ke UUD 1945 tidak mengatur sama sekali kewenangan pengadilan untuk menilai secara materil undang-undang baik dalam batang tubuh maupun penjelasannya. Sebagaimana telah diketahui UUD 1945 adalah suatu naskah yang sangat singkat (summier). Ia hanya berisi prinsip-prinsip umum serta menyerahkan pengaturan selanjutnya kepada perundang-undangan yang lebih rendah. ${ }^{34}$ hal. 42 .

${ }^{32}$ Ismail Sunny, "Pembagian Kekuasaan Negara", cet. Ke-dua, (Jakarta: Aksara Baru, 1978),

\footnotetext{
${ }^{33}$ Asshiddiqie (c), Op. Cit., hal. 582.

${ }^{34}$ Ibid., hal. 42-47.
} 
Dengan demikian dalam sistem konstitusi Indonesia sebelum pasca amandemen UUD (Tahun 2000) tidak mengenal badan peradilan dapat mengontrol atau mempengaruhi badan eksekutif atau legislatif. Hal ini dipengaruhi sistem hukum yang berlaku di Negeri Belanda yaitu suatu ketentuan yang tidak memperkenankan pengadilan menilai isi (materieel toetsingsrecht) suatu undang-undang, dengan mengatakan bahwa "undang-undang tidak dapat diganggu gugat", atau dengan perkataan lain "hak untuk menentukan apakah suatu undang-undang bertentangan dengan Undang-Undang Dasar adalah soal pembentuk undang-undang dan bukan soal hakim".

Pasca reformasi dengan harapan terselenggaranya pemerintahan yang lebih demokratis, dilakukan politik hukum ketatanegaraan yakni amandemen terhadap UUD 1945, dan merupakan hal yang tabu dalam pemerintahan sebelumnya (Orba). Sesuatu yang baru dalam sejarah hukum ketatanegaraan Indonesia yaitu lahirnya Mahkamah Konstitusi ( 16 Agustus 2003) sebagai salah satu bentuk dari pelaku kekuasaan kehakiman menurut konstitusi UUD 1945. Keberadaan Mahkamah Konstitusi dengan kewenangan utama melakukan pengujian (judicial review) undang-undang terhadap UUD 1945, sebagai wujud hukum di atas segala-segalanya (supremacy of law). Hal ini melemahkan pemikiran Negara Hukum Integralistik sebagaimana yang dikemukakan oleh Soepomo, dan beralih kepada sistem ketatanegaraan "Separation of power" berdasarkan 'checks and balances'.

\begin{abstract}
Kewenangan konstitusional Mahkamah Konstitusi melaksanakan prinsip checks and balances yang menempatkan semua lembaga negara dalam kedudukan setara sehingga terdapat keseimbangan dalam penyelenggaraan negara. Keberadaan Mahkamah Konstitusi merupakan langkah nyata untuk dapat saling mengoreksi kinerja antar lembaga Negara. ${ }^{35}$
\end{abstract}

Amanat Pasal 24C ayat (6) UUD 1945 ditindaklanjuti dengan disahkan dan diundangkankannya Undang-Undang Nomor 24 Tahun 2003 tentang Mahkamah Konstitusi (LN RI Thn. 2003 Nomor 98-TLN RI Nomor 4316). Disebutkan dalam bagian penjelasan umum Undang-Undang tersebut, Mahkamah Konstitusi merupakan salah satu pelaku kekuasaan kehakiman, disamping Mahkamah Agung sebagaimana dimaksud dalam Pasal 24 ayat (1) dan ayat (2) UUD Negara Republik

${ }^{35}$ Indonesia, (c), Undang-Undang Mahkamah Konstitusi, UU No. 24 Tahun 2003, LN No.98 Tahun 2003, TLN No. 4316, Penjelasan umum, aline. 3. 
Indonesia tahun 1945. Hal ini berarti Mahkamah Konstitusi terikat pada prinsip umum penyelenggaraan kekuasaan kehakiman yang mandiri, merdeka, bebas dari pengaruh kekuasaan lembaga lainnya dalam menegakkan hukum dan keadilan. ${ }^{36}$

Adapun yang menjadi pertimbangan hukum diundangkannya Undang-Undang Nomor 24 Tahun 2003 tentang Mahkamah Konstitusi, adalah sebagai berikut:

1. Bahwa Negara kesatuan Republik Indonesia merupakan negara hukum yang berdasarkan Pancasila dan Undang-Undang Dasar Negara Republik Indonesia Tahun 1945, bertujuan untuk mewujudkan tata kehidupan bangsa dan negara yang tertib, bersih, makmur dan berkeadilan;

2. Bahwa Mahkamah Konstitusi sebagai salah satu pelaku kekuasaan kehakiman mempunyai peranan penting dalam usaha menegakkan konstitusi dan prinsip negara hukum sesuai dengan tugas dan wewenangnya sebagaimana ditentukan dalam Undang-Undang Dasar Negara Republik Indonesia Tahun 1945;

3. Bahwa berdasarkan ketentuan Pasal $24 \mathrm{C}$ ayat (6) Undang-Undang Dasar Negara Republik Indonesia Tahun 1945 perlu mengatur tentang pengangkatan dan pemberhentian hakim konstitusi, hukum acara dan ketentuan lainnya tentang Mahkamah Konstitusi. ${ }^{37}$

Atas dasar pertimbangan hukum tersebut di atas, keberadaan Mahkamah Konstitusi sebagai salah satu pelaku kekuasaan kehakiman yang diberi wewenang khusus untuk mengadili perkara ketatanegaraan atau perkara konstitusi, dalam rangka menjaga dan menegakkan konstitusi agar dilaksanakan secara bertanggung jawab sesuai dengan kehendak rakyat dan cita-cita demokrasi. Keberadaan Mahkamah Konstitusi sekaligus untuk menjaga terselenggaranya pemerintahan negara yang stabil, untuk mewujudkan tata kehidupan bangsa dan negara yang tertib, bersih, makmur dan berkeadilan. Oleh karena itu, Mahkamah konstitusi selain sebagai penjaga konstitusi (the guardin of the constitution), juga merupakan penafsir tertinggi konstitusi (the sole interpreter of constitution). ${ }^{38}$

Sebagai salah satu pelaku kekuasaan kehakiman dalam rangka "the guardin of the constitution" dan "the sole interpreter of constitution", Mahkamah Konstitusi diberi wewenang khusus (atribusi) oleh Undang-Undang Dasar 1945, yang

\footnotetext{
${ }^{36}$ Ibid., Penjelasan umum, alinea. 2.

${ }^{37}$ Ibid., Bagian Konsideran Dasar Menimbang.

${ }^{38}$ Fajar, Loc. cit., hal. 119.
} 
selanjutnya di tindaklanjuti dalam ketentuan Pasal 10 Undang-Undang Nomor 24 Tahun 2003 tentang Mahkamah Konstitusi, yaitu:

Ayat (1):

a. Menguji undang-undang terhadap Undang-Undang Dasar Negara Republik Indonesia Tahun 1945;

b. Memutus sengketa kewenangan lembaga negara yang kewenangannya diberikan oleh Undang-Undang Dasar Negara Republik Indonesia Tahun 1945;

c. Memutus pembubaran partai politik; dan

d. Memutus perselisihan tentang hasil pemilihan umum.

Ayat (2):

Mahkamah Konstitusi wajib memberikan putuasan atas pendapat DPR bahwa Presiden dan/atau Wakil Presiden diduga telah melakukan pelanggaran hukum berupa penghianatan terhadap negara, korupsi, penyuapan, tindak pidana berat lainnya, atau perbuatan tercela, dan/atau tidaklagi memenuhi syarat sebagai Presiden dan/atau Wakil Presiden sebagaimana dimaksud dalam Undang-Undang Dasar Negara Republik Indonesia Tahun $1945 .{ }^{39}$

Dari beberapa kewenangan yang dimiliki Mahkamah Konstitusi tersebut, menarik untuk ditelaah adalah kewenangan pengujian yudisial Mahkamah Konstitusi atas peraturan perundang-undangan, terbatas sepanjang peraturan undang-undang. Dilain pihak pengujian yudisial peraturan perundang-undang di bawah undangundang terhadap peraturan perundang-undangan yang lebih tinggi menjadi kewenangan Mahkamah Agung (Pasal 24A ayat 1 UUD 1945 Jo. Pasal 31 ayat 1 UU No.5 Tahun 2004). Hal ini menurut Prof. DR. Moh. Mahfud MD (Ketua Mahkamah Konstitusi), "bahwa pengaturan UUD 1945 tersebut adalah kurang tepat, terdapat kewenangan silang yang kurang singkron antara Mahkamah Konstitusi dan Mahkamah Agung dalam menangani konplik antar peraturan dan konplik antar orang/lembaga". ${ }^{40}$ Selanjutnya beliau mengemukakan:

Dalam pengaturan sekarang (UUD 1945), Mahkamah Agung menangani konplik antar orang/lembaga sebagai peradilan konvensional sekaligus

\footnotetext{
${ }^{39}$ Indonesia, (c), Op. Cit., Pasal 10 ayat (1) dan ayat (2).

${ }^{40}$ M.D., Op. Cit., hal. 284.
} 
menangani konplik antar peraturan (pengujian yudisial), sedangkan Mahkamah Konstitusi menangani konplik antar peraturan sebagai peradilan ketatanegaraan sekaligus menangani konplik antara orang/lembaga dalam hal-hal tertentu. Untuk konplik antar peraturan yang memerlukan pengujian yudisial sebagainya diletakkan seluruhnya di bawah Mahkamah Konstitusi sebagai peradilan ketatanegaraan. Artinya pengujian undang-undang terhadap UUD dan pengujian peraturan perundang-undangan dibawah undang-undang terhadap peraturan perundang-undangan yang derajatnya yang lebih tinggi semuanya dijadikan kewenangan Mahkamah Konstitusi. Hal ini dimaksudkan agar ada konsentrasi dan konsistensi penafsiran semua peraturan perundang-undangan dari yang paling tinggi (UUD) sampai yang paling rendah (Perda). ${ }^{41}$

Tentang pembagian kewenangan pengujian peraturan (judicial review) atas peraturan perundang-undangan antara Mahkamah Agung dan Mahkamah Konstitusi yang diatur dalam UUD 1945, juga mendapat kritik dari Prof. DR. Jimly Assidddiqie, S.H., M.H., (mantan Ketua Mahkamah Konstitusi), sebagaimana dikemukakan oleh beliau:

Pembagian demikian sama sekali tidak ideal, karena dapat menimbulkan perbedaan atau putusan yang saling bertentangan antara Mahkamah Konstitusi dengan Mahkamah Agung. Yang paling sering saya jadikan contoh hipotetis adalah berkenan dengan keabsahan materiel PP No. 110 Tahun 2000 dibandingkan dengan UU No. 22/1999 di satu pihak, dan keabsahan UU No. $22 / 1999$ dibandingkan dengan Pasal 18 UUD 1945 di pihak lain. Misalnya, dapat saja terjadi Mahkamah Agung memutuskan bahwa PP No. 110/2000 tersebut bertentangan dengan UU No. 22/1999, sementara pada saat yang sama Mahkamah Konstitusi memutuskan UU No. 22/1999 itu bertentangan dengan UUD 1945;

Perbedaan ini tidak terlepas dari kenyataan sebelumnya dimana Mahkamah Agung berwenang menguji peraturan perundang-undangan di bawah undang-undang. Bahkan ketentuan demikian ditegaskan pula dalam Ketetapan MPR No. III/MPR/2000, karenan itu ketika sepakat

${ }^{41}$ Ibid., hal. 284-285. 


\section{diadopsinya ide pembentukan Mahkamah Konstitusi dalam Perubahan Ketiga UUD 1945 pada tahun 2001, maka ketentuan lama berkenan dengan kewenangan Mahkamah Agung itu dituangkan dalam rumusan ketentuan Pasal 24A Perubahan Ketiga UUD 1945 tersebut. ${ }^{42}$}

Dilihat dari hierarki peraturan perundang-undangan, tentang hal tersebut menarik untuk dikemukakan teori Hans kelsen yang dikembangkan oleh muridnya Hans Nawiasky dalam bukunya "Allgemeine Rechtslehre", Dimana suatu norma yang lebih rendah berlaku bersumber dan berdasar pada norma yang lebih tinggi, dan norma yang lebih tinggi berlaku bersumber dan berdasar pada norma yang lebih tinggi lagi, demikian seterusnya sampai pada suatu norma yng tidak dapat ditelusuri lebih lanjut dan bersifat hipotetis dan fiktif, yaitu norma dasar (grundnorm). Bahwa norma hukum tersebut selain berjenjang dan berlapis juga berkelompok-kelompok. Dalam tatanan peraturan perundang-undangan Indonesia norma hukum tersebut sebagimana yang ditetapkan dalam Pasal 7 ayat (1) Undang-Undang Nomor 11 Tahun 2011, yaitu: (i) Undang-Undang Dasar Negara Republik Indonesia Tahun 1945 (Staatsgrundgesetz/Aturan Dasar), (ii) Undang-Undang/Peraturan Pemerintah Pengganti Undang-ndang (Formell Gesetz/Undang-Undang 'formal'), (iii) Peraturan Pemerintah, (iv) Peraturan Presiden, dan (v) Peraturan Daerah (Verordenung/Aturan Pelaksana).

Secara hirarkhis peraturan perundang-undangan tersebut merupakan satu kesatuan sistem hukum yang berlandaskan pada prinsip hukum, bahwa peraturan yang dibawah berlaku, berdasar, dan bersumber pada peraturan yang lebih tinggi dan peraturan yang lebih tinggi berlaku, berdasar, dan bersumber pada peraturan yang lebih tinggi lagi. Dalam hal ini peraturan perundang-undangan dibawah UndangUndang yaitu (iii)Peraturan Pemerintah, (iv) Peraturan Presiden, dan (v) Peraturan Daerah (sebagai peraturan pelaksana/Verordnung ) berlaku, berdasar, dan bersumber pada (ii) Undang-Undang (Formell Gesetz), dan selanjutnya kepada yang lebih tinggi lagi yaitu (i) Undang-Undang Dasar Negara Republik Indonesia Tahun 1945 (Staatsgrundgesetz/Aturan Dasar). Oleh karenanya pemisahan pengujian peraturan (judicial review) yang dilakukan oleh 2(dua) lembaga peradilan yang berbeda, akan menimbulkan ketidaksesuaian dalam penafsiran hukum.

Hal lain yang perlu dipertimbangkan bahwa dalam praktek ketatanegaraan peraturan perundang-undangan di bawah Undang-Undang yang menjadi produk pemerintahan sebagai badan politik, bukan tidak mungkin melanggar konstitusi UUD

${ }^{42}$ Assihiddiqie, (b), Op. Cit., hal. 189. 
1945. Hal ini menimbulkan permasalahan hukum ketatanegaraan, oleh karena tidak tersedianya jalur penyelesaian hukum (peradilan). Disamping itu pemisahan lembaga pengujian (judicial review) peraturan perundang-undangan akan menimbulkan penafsiran yang berbeda yang bertentangan dengan cita-cita hukum.

Kelemahan-kelemahan pengaturan pengujian peraturan (judicial review) tersebut, menimbulkan kontroversi issu yang berkembang. Untuk itu diperlukannya pemikiran politik hukum dalam perubahan UUD 1945, sehingga tidak melanggar cita-cita hukum itu sendiri. Sebagaimana yang dikemukakan oleh Prof. DR. Jimly Assidddiqie: “

Terlepas dari kelemahan ini, biarlah untuk sementara waktu pembagian demikian diterima dan dipraktekkan dulu pada tahap-tahap awal pertumbuhan lembaga Mahkamah Konstitusi ini di Indonesia. Namun untuk jangka panjang, memang harus dipikirkan kemungkinan mengintegrasikan seluruh sistem pengujian peraturan di bawah kewenangan Mahkamah Konstitusi. Dengan demikian, keadilan bagi warga negara dapat diwujudkan secara integral di bawah fungsi Mahkamah Agung, sedangkan peradilan atas sistem hukum dan peraturan perundang-undangan diletakkan di bawah pengawasan Mahkamah Konstitusi. ${ }^{43}$

Dengan demikian sebelum dilakukannya pengintegrasian sistem pengujian peraturan perundang-undangan di bawah kewenangan Mahkamah Konstitusi secara normatif, dalam praktek peradilan dengan berlandaskan pada cita-cita hukum dan prinsip peradilan, "Pengadilan tidak boleh menolak untuk memeriksa, mengadili dan memutus suatu perkara yang diajukan dengan dalih bahwa hukum tidak ada dan atau kurang jelas, melainkan wajib untuk memeriksa dan mengadilinya". ${ }^{44}$ Adalah sangat beralasan Mahkamah Konstitusi dapat melakukan pengujian peraturan (judicial review) atas peraturan perundang-undangan di bawah Undang-Undang terhadap Undang-Undang Dasar 1945.

${ }^{43}$ Ibid., hal. 190.

44 Indonesia, (d), Undang-Undang Kekuasaan Kehakiman, UU No. 4 Tahun 2004, LN No.8 Tahun 2004, TLN No. 4358, Pasal 16 ayat (1). 


\section{Kesimpulan}

Momentum tuntutan reformasi hukum dilakukannya politik hukum, melalui Sidang Umum MPR atas dasar ketentuan Pasal 37 UUD Tahun 1945 dilakukannya perubahan (amandemen) terhadap Undang-Undang Dasar Tahun 1945. Setelah amandemen UUD 1945, kekuasaan kehakiman sebagai salah satu kekuasaan negara tidak lagi menjadi bagian dari kekuasaan eksekutif secara organisatoris, administratif dan finansial. Kekuasaan kehakiman adalah kekuasaan hukum yang mandiri, merdeka, bebas dari intervensi pihak manapun yang diselenggarakan oleh Mahkamah Agung dan Mahkamah Konstitusi. Pasal 24 ayat (2) UUD 1945, "Kekuasaan kehakiman dilakukan oleh sebuah Mahkamah Agung dan badan peradilan yang berada dibawahnya dalam lingkungan peradilan umum, lingkungan peradilan agama, lingkungan peradilan militer, lingkungan peradilan tata usaha, dan oleh sebuah Mahkamah Konstitusi".

Menarik untuk ditelaah adalah keberadaan Mahkamah Konstitusi, sebagai salah satu bentuk dan pelaku kekuasaan kehakiman yang sebelumnya tidak pernah dikenal sama sekali dalam sistem ketatanegaraan Indonesia. Secara filosofis ide dasar pembentukan Mahkamah Konstitusi adalah untuk menciptakan sebuah sistem ketatanegaraan di Indonesia yang menganut asas pemisahan kekuasaan (separation of power) secara fungsional dan menerapkan "check and balances". Dalam negara konstitusional dan demokratis keberadaan Mahkamah Konstitusi sebagai lembaga pengawal konstitusi (the guardian of the constitution) dengan kewenangan yang dimiliki melakukan pengujian peraturan "judicial review", untuk menjamin agar norma dasar (konstitusi) yang terkandung didalamnya sungguh-sungguh ditaati dan dilaksanakan, secara bertanggung jawab sesuai dengan kehendak rakyat dan cita-cita demokrasi. Selaku pengawal konstitusi (the guardian of the constitution) Mahkamah Konstitusi sebagai badan peradilan pada tingkat pertama dan terakhir diberi kewenangan untuk melakukan pengujian (judicial review) undang-undang terhadap Undang-Undang Dasar, sebagaimana yang disebutkan dalam Pasal 24C UUD 1945.

Menjadi persoalan adalah kewenangan Mahkamah Konstitusi melakukan pengujian (judicial review) atas peraturan perundang-undangan, terbatas sepanjang Undang-Undang. Dilain pihak pengujian yudisial peraturan perundang-undang di bawah undang-undang terhadap peraturan perundang-undangan yang lebih tinggi menjadi kewenangan Mahkamah Agung (Pasal 24A ayat 1 UUD 1945 Jo. Pasal 31 ayat 1 UU No.5 Tahun 2004). Hal ini menimbulkan kontroversi issu yang berkembang dan mendapat kritikan dari pakar hukum tata negara Prof. Dr. Moh. Mahfud M.D. (Ketua Mahkamah Konstitusi) dan Prof. Dr. Jimly Assidddiqie, S.H., M.H., (mantan Ketua Mahkamah Konstitusi). 
Prof. Dr. Moh. Mahfud M.D., mengemukakan:

Bahwa pengaturan UUD 1945 tersebut adalah kurang tepat, terdapat kewenangan silang yang kurang singkron antara Mahkamah Konstitusi dan Mahkamah Agung dalam menangani konplik antar peraturan dan konplik antar orang/lembaga."

Prof. Dr. Jimly Assidddiqie, S.H., M.H., mengemukakan:

Pembagian demikian sama sekali tidak ideal, karena dapat menimbulkan perbedaan atau putusan yang saling bertentangan antara Mahkamah Konstitusi dengan Mahkamah Agung. Yang paling sering saya jadikan contoh hipotetis adalah berkenan dengan keabsahan materiel PP No. 110 Tahun 2000 dibandingkan dengan UU No. 22/1999 di satu pihak, dan keabsahan UU No. $22 / 1999$ dibandingkan dengan Pasal 18 UUD 1945 di pihak lain. Misalnya, dapat saja terjadi Mahkamah Agung memutuskan bahwa PP No. 110/2000 tersebut bertentangan dengan UU No. 22/1999, sementara pada saat yang sama Mahkamah Konstitusi memutuskan UU No. 22/1999 itu bertentangan dengan UUD 1945;

Dalam praktek peradilan dengan berlandaskan pada cita-cita hukum dan prinsip peradilan, bahwa Pengadilan tidak boleh menolak untuk memeriksa, mengadili dan memutus suatu perkara yang diajukan dengan dalih bahwa hukum tidak ada. Untuk itu adalah sangat beralasan Mahkamah Konstitusi dapat melakukan pengujian peraturan (judicial review) atas peraturan perundang-undangan di bawah Undang-Undang terhadap Undang-Undang Dasar 1945. 


\section{Daftar Referensi}

Algra, Mr. N.E., dkk. Kamus Istilah Hukum Fockema Andreae BelandaIndonesia. Cet. Pertama. Jakarta: Binacipta, 1983.

Assiddiqie, Jimly. Konstitusi \& Konstitusionalisme Indonesia. Cet. Ke-satu. Jakarta: Mahkamah Konstitusi RI \& Pusat Studi Hukum Tata Negara FHUI, 2004.

Asshidiqie, Jimly. Model-Model Pengujian Konstitusional Di Berbagai Negara. Cet. Ke-dua. Jakarta: KONpress,2005.

Asshiddiqie, Jimly. Pokok-Pokok Hukum Tata Negara Indonesia. Cet. Ke-dua. Jakarta: PT. Bhuana Ilmu Populer, 2008.

Budiardjo, Miriam. Dasar-Dasar Ilmu Politik. Cet. Ke-tiga. Jakarta: PT. Gramedia, 1977.

Fadjar, Abdul Mukthie. Hukum Konstitusi Dan Mahkamah Konstitusi. Cet. Ke-satu. Jakarta: KONpress, 2006.

Fatwa, A.M. Potret Konstitusi Pasca Amandemen UUD 1945. Cet. Ke-satu. Jakarta: PT. Gramedia, 2009.

Hutabarat, Ramly. Politik Hukum Pemerintahan Soeharto Tentang Demokrasi Politik Di Indonesia. Cet. Ke-satu. Jakarta: Pascasarjana FHUI, 2004.

John M. Echols dan Hasan Shadely. Kamus Inggris-Indonesia. Cet. Ke-lima belas. Jakarta: PT. Gramedia, 1987.

M.D., Moh. Mahfud. Konstitusi Dan Hukum Dalam Kontroversi Isu. Cet. Kesatu. Jakarta: PT. RadjaGrafindo Persada, 2009.

Soeprapto, Maria Farida Indrati. Ilmu Perundang-Undangan Dasar-dasar dan Pembentukannya. Cet. Ke-sebelas. Jakarta: Kanisius, 1998.

Sunny, Ismail. Pembagian Kekuasaan Negara. Cet. Ke-dua. Jakarta: Aksara Baru, 1978.

Thalib, Abdul Rasyid. Wewenang Mahkamah Konstitusi dan Imlikasinya dalam Sistem Ketatanegaraan Republik Indonesia. Cet. Ke-satu, Bandung: PT. Citra Aditya Bakti, 2006. 


\section{Peraturan Perundang-Undangan}

Indonesia. Undang - Undang Dasar 1945.

Indonesia. Undang-Undang Mahkamah Konstitusi. UU No. 24 Tahun 2003. LN No.98 Tahun 2003, TLN No. 4316.

Indonesia. Undang-Undang Kekuasaan Kehakiman. UU No. 4 Tahun 2004. LN No.8 Tahun 2004, TLN No. 4358.

Indonesia. Undang-Undang tentang Pembentukan Peraturan PerundangUndangan. UU No. 11 Tahun 2011. LN No. 53 Tahun 2004, TLN No. 4389.

\section{Makalah}

Manan, Bagir. Ketentuan-Ketentuan Tentang Pembentukan Peraturan Perundang-Undangan Daklam Pembangunan Hukum Nasional. Makalah disampaikan pada pertemuan ilmiah tentang Kedudukan Biri-biro Hukum/Unit Kerja Departemen/LPND dalam Pembangunan Hukum, (Jakarta 19-20 Oktober 1994). 